\title{
Operationalising loT for reverse supply: the development of use-visibility measures
}

\author{
Glenn C. Parry \\ Bristol Business School, University of the West of England, Bristol, UK and \\ School of Management, University of Bath, Bath, UK \\ Saara A. Brax \\ School of Science (DIEM), Aalto University, Espoo, Finland \\ Roger S. Maull \\ University of Surrey Business School, University of Surrey, Guildford, UK, and \\ Irene C.L. $\mathrm{Ng}$ \\ Warwick Manufacturing Group (WMG), University of Warwick, Coventry, UK
}

\begin{abstract}
Purpose - Improvement of reverse supply chains requires accurate and timely information about the patterns of consumption. In the consumer context, the ways to generate and access such use-visibility data are in their infancy. The purpose of this study is to demonstrate how the Internet of Things (loT) may be operationalised in the domestic setting to capture data on a consumer's use of products and the implications for reverse supply chains.

Design/methodology/approach - This study uses an explorative case approach drawing on data from studies of six UK households. "Horizontal" data, which reveals patterns in consumers' use processes, is generated by combining "vertical" data from multiple sources. Use processes in the homes are mapped using IDEF0 and illustrated with the data. The quantitative data are generated using wireless sensors in the home, and qualitative data are drawn from online calendars, social media, interviews and ethnography.

Findings - The study proposes four generic measurement categories for operationalising the concept of use-visibility: experience, consumption, interaction and depletion, which together address the use of different household resources. The explorative case demonstrates how these measures can be operationalised to achieve visibility of the context of use in the home. The potential of such use-visibility for reverse supply chains is discussed. Research limitations/implications - This explorative case study is based on an in-depth study of the bathroom which illustrates the application of use-visibility measures (UVMs) but provides a limited use context. Further research is needed from a wider set of homes and a wider set of use processes and contexts.

Practical implications - The case demonstrates the operationalisation of the combination of data from different sources and helps answer questions of "why?", "how?", "when?" and "how much?", which can inform reverse supply chains. The four UVMs can be operationalised in a way that can contribute to supply chain visibility, providing accurate and timely information of consumption, optimising resource use and eliminating waste.

Originality/value - IDEF0 framework and case analysis is used to identify and validate four UVMs available through loT data - that of experience, consumption, interaction and depletion. The UVMs characterise loT data generated from a given process and inform the primary reverse flow in the future supply chain. They provide the basis for future data collection and development of theory around their effect on reverse supply chain efficiency.
\end{abstract}

Keywords Visibility, Internet of Things, Business performance, Closed loop supply, Reverse supply chain

Paper type Research paper

\section{Introduction}

Inefficient reverse supply chains hold significant opportunities for economic and sustainability improvements. Every day each person in the UK uses 150 litres of water (WaterWise, 2012). In 2013, the UK produced 26.5 million tonnes of domestic waste, equivalent to $416 \mathrm{~kg}$ per person (DEFRA, 2015). Electrical product returns cost UK producers $£ 400 \mathrm{~m}$ per annum (WRAP, 2014). Also, $£ 220 \mathrm{~m}$ is lost in inefficient

The current issue and full text archive of this journal is available on Emerald Insight at: www.emeraldinsight.com/1359-8546.htm

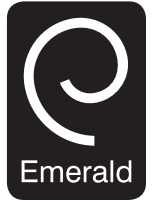

Supply Chain Management: An International Journal 21/2 (2016) 228-244

Emerald Group Publishing Limited [ISSN 1359-8546] [DOI 10.1108/SCM-10-2015-0386]
C Parry, Brax, Maull, Ng. Published by Emerald Group Publishing Limited. This article is published under the Creative Commons Attribution (CC BY 3.0) licence. Anyone may reproduce, distribute, translate and create derivative works of this article (for both commercial \& non-commercial purposes), subject to full attribution to the original publication and authors. The full terms of this licence may be seen at http://creativecommons.org/licences/by/ 3.0/legalcode

The authors gratefully acknowledge the funding contribution of the Research Council (UK) Digital Economy to the H.A.T project (http:/hubofallthings. org) grant reference EP/K039911/1, NEMODE EP/K003542/1 and the Academy of Finland (grant no 274327) which has contributed substantially to the research conducted and the writing of this paper. The authors are also grateful to Dr Ganna Pogrebna and Yin Lim for their help and valued support.

Received 19 January 2015

Revised 20 July 2015

3 October 2015

13 November 2015

Accepted 16 November 2015 
material recycling, as only 24 per cent of the 2.5 million tonnes of plastic packaging used was recycled (WRAP, 2014). The total waste provides an opportunity for business to develop smarter reverse supply chains that are able to develop and support longer life products, which for electrical goods alone could be worth $£ 800 \mathrm{~m}$ per annum. These numbers indicate that even small improvements in reverse supply chains can translate to significant benefits in materials, time and cost savings, benefiting firms, customers and the environment.

Supply chain management is a boundary spanning activity (Fawcett et al., 2008; Sarkis, 2012). As firms are increasingly considered responsible for the impact of their products, consideration must be given to a products supply, its use, recovery, recycling and disposal (Ashby et al., 2012). We focus upon consumer use process as the beginning of the reverse supply chain. We propose that useful context-specific data can be captured and used to understand the "what?", "when?" and "why?" of household's consumption activities and improve front-end collaboration in reverse supply chains.

A reverse supply chain is often difficult to manage due to information asymmetry (Brynjolfsson et al., 2011). In the context of the home, the consumer has knowledge of the functional activities, but little information is passed from the home back to the supplier. Thus, suppliers usually lack post-sales visibility of their products in the domestic context of use. We argue that the contexts of use are where the reverse supply chains begin, where the product is used in combination with other resources and then enters the reverse supply. Studies have suggested that the consumers' side of the supply chain should be examined from the perspective of consumer operations (Maull et al., 2012, p. 79; Sampson, 2012), recognising that the use value of a product or a service is situated in a consumer's specific context (Vargo and Lusch, 2008; Gummesson and Mele, 2010; Edvardsson et al., 2014; ONS - Office of National Statistics, 2013) and generated by the customers through their resource integrating activities (Moeller, 2008). Understanding consumption practices in the home requires visibility of the domestic part of the supply chain that is currently hidden. Therefore, this study explores the potential of increasing visibility of consumer use processes and considers how access to data on visibility can improve reverse supply chain performance.

Visibility refers to a firms ability to access data which allows them to "see" into their supply chains (Bradley, 2002). Research has shown that an increase in supply chain visibility (SCV) enhances performance through improved inventory management, higher sales and better understanding of demand (Gavirneni et al., 1999; Lee and Whang, 2000; Yu et al., 2001; Kulp, 2002; Kaipia and Hartiala, 2006). The benefits of increased visibility can be significant; Gavirneni et al. (1999) report a 35 per cent cost reduction and Lee et al. (2000) found that inventory reductions of up to 40 per cent were achieved through sharing retailers' data. We argue that visibility is similarly important to the reverse supply chains as it is for the forward supply chain.

Visibility information about use processes has been discussed in the context of business-to-business (B2B) and industrial solutions, where asset management information systems provide direct access to the customer information required for service provision (Holmström et al., 2010).
Development of reverse supply chains in the consumer context has been limited by the difficulty of accessing visibility information. Internet technologies mean that the quantity and speed of consumer data availability has changed, creating new channels through which consumers interact and firms capture data, creating insight into consumer behaviour (Bustinza et al., 2013). This study explores the use of Internet of Things (IoT) technologies as a means to generate visibility data, capturing consumer consumption practices in the home.

We envision that the IoT will enable visibility of consumer use of goods and services (Brody and Pureswaran, 2015), and we identify the IoT as providing an opportunity to gather rich data on the relationship between everyday objects and individuals (Santucci, 2011). Data about the use of the product can help alleviate the uncertainties in the timing of product returns and provide information relating to the condition of a returned product (Guide and van Wassenhove, 2002). Reverse logistics has a strong dependence on consumer behaviour and preferences which influence the quality and quantity of product returns (Srivastava, 2008). Literature describes vertical integration and information sharing when focusing on the supply of a single service or a good. We use the term "vertical data" for visibility information that covers such a single-product supply chain. Whilst horizontal integration and information sharing refers to collaboration with parties that may compete against each other, we use the term "horizontal data" to refer to visibility collected from multiple data verticals. The IoT gives firms the opportunity to collect more data; we argue that both research and practice in SCV currently focuses on a single "vertical" supply chain, with data collected by firms only on their product or service. We argue that such a narrow approach limits what the firm can know about the use of their offering and suggest that the understanding of consumption visibility requires a broader approach. Our paper investigates multiple verticals of consumption data at a point in time, that is, the "horizontal data" that provides context of use, which can be obtained through IoT. In this paper, we present a case study of a horizontal set of data from a data platform, which is a data schema and repository that captures data from and for an individual across many verticals of use and consumption[1]. By combining multiple "verticals" at a point in time to generate horizontal data sets, it is possible to gain visibility of contexts of use and begin to uncover the practices and reasons behind consumer action and rates of consumption.

We contribute to the reverse supply chain literature, and to the research on SCV, by providing a categorisation of consumer use data and empirically demonstrate the use of the categorisation in an example case study. We propose four categories of UVMs that address the main dimensions of consumers' use of resources: depletion, consumption, interaction and experience. The consumer's process is taken as the primary level of analysis, instead of, for example, the usage of a single product. Analysis of the contextual use process gives data on consumers' rates of use and allows understanding of consumption processes and patterns. Our implementation of the four UVM categories demonstrates how information about the use in context, for a specific product, could be obtained through IoT instrumentation. 
We operationalise the four measures by using data of six volunteer households in the UK with different sensors. The quantitative data are supplemented by qualitative data captured from social media applications and ethnographic style field work. IDEF0 process mapping captures the story of the home processes. Graphs show the data from the IoT sensors and the analysis explains how the measures provide visibility of consumer context of consumption for use in forward and reverse supply chains (Dutton, 2014). We then discuss how context-specific information about domestic use process gives visibility of previously hidden activity of actual use, consumption and waste for forward and reverse supply chain activities (Holmström et al., 2010; Ghiassi and Spera, 2003). Integrating the findings with literature, we also discuss how negotiating access to IoT data collected from individuals can support closed loop supply chains.

The article is structured as follows: in the following section, the literature review addresses the limitations in existing reverse supply chain research and examines the role of visibility in understanding context-specific use processes which can inform reverse supply. The third section describes the research method which is followed by the case analysis of IoT data collected in the households. The conclusion and discussion section, then, addresses the implications for IoT data on reverse supply chains, limitations and suggestions for further research.

\section{Literature review}

\subsection{Reverse supply chains}

Current integrative views on supply chains have changed the perspective of an individual organisation from "being a supplier" to being a part of both forward and reverse supply chains (Fuente et al., 2008; Govindan and Popiuc, 2014). Reverse supply chains have similar competence and resource requirements to forward supply, but they differ at the level of operational sub-processes and flows (Fleischmann et al., 2000; Tibben-Lembke and Rogers, 2002). Forward and reverse supply chain management involves companies coordinating with their suppliers, wholesalers, retailers and consumers to achieve sustainable competitive advantages in their respective markets (Cooper et al., 1997) with supply chain competence empirically linked to firm performance (Ellinger et al., 2012). In reverse supply, the increased uncertainties associated with volume, evaluation, rework and waste materials are particularly challenging and mean that firms take on an associate risk which can be minimised with more complete information (Kocabasoglu et al., 2007).

Fischer's (1997) distinction between functional and innovative products has been adapted for reverse supply chains by Blackburn et al. (2004). Where Fisher (1997) classifies supply chains in terms of outbound product supply, reverse supply chains have been perceived "as a nuisance" and, hence, are often designed to minimise cost of processing returns, not recovery of value (Blackburn et al., 2004). Blackburn et al. (2004) apply Fischer's concepts of time-based marginal value to the construct of the reverse supply chain. The loss in value per unit of time spent waiting for return or recovery can be significant, with power tools losing approximately 1 per cent per month and a PC up to 1 per cent per week in value. Return processes which take three to four months are not untypical, eroding the economic value of the product and making landfill economically more favourable.

Figure 1 presents the generic closed loop which combines forward and reverse supply chain (Blackburn et al., 2004; Wells and Seitz, 2005; Loomba and Nakashima, 2012, p. 206; Govindan and Popiuc, 2014; El Korchi and Millet, 2014, p. 10). Wells and Seitz (2005) describe retail closed loop supply as "post-consumer" loops, where the consumer becomes a point of stock holding for a product until it is sent back into reverse supply. In Figure 1, a decoupling point has been drawn by the authors, as after the point of exchange with the consumer, the supply chain has limited data or information as to the volumes, use, context, time of return, etc., of the product. The product and its use in context are hidden from the view of the suppliers until either the consumer returns the item to a retailer or uses a disposal/ recycling supply chain.

Planning reverse supply is challenging, primarily due to the high uncertainty involved (Guide et al., 2000). Whilst traditional forecasting and data facilitate batch manufacture for forward supply, such inventory models do not apply, as the arrival of product into reverse supply tends to be reactive to actions of downstream consumers (Tibben-Lembke and Rogers, 2002). The sorting and diagnostic phases of reverse supply is a much greater challenge than in forward supply chains, where the product condition is significantly more homogeneous and planning enables the optimisation of resource utilisation (Thierry et al., 1995). In proposing the reverse supply structure, Blackburn et al. (2004) and others suggest that the positioning of the evaluation activity in the supply chain provides the major structural difference between efficient and responsive reverse supply. Efficient reverse supply chains require a centralised evaluation activity to keep volume high and costs low by allowing for breakdown of processes into specialised areas where process flows can reach steady states. Alternatively, responsive reverse supply chains require numerous decentralised evaluation activities to minimise the time in processing returns, which has higher cost (Santibanez-Gonzalez and Diabat, 2013). The positioning of the evaluation activity does not seek to enhance the ability to determine the condition of the returned products swiftly and inexpensively, as this would require data regarding the state and use life of the product, something not currently available.

Figure 1 Generic integrated forward and reverse supply chain

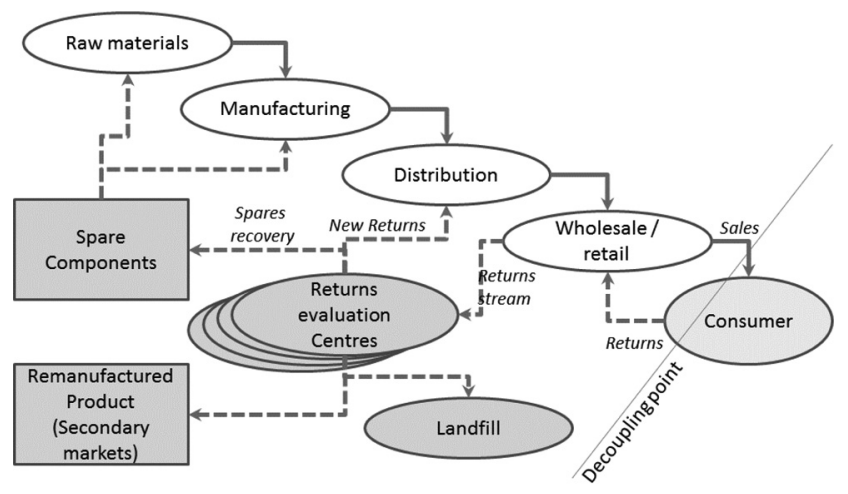

Source: Adapted from Blackburn et al. (2004) 
The current approaches to reverse supply chain design do not afford the end consumer any agency in offering or trading their data back to the provider. Whilst data on product demand reduces uncertainty related to volumes and variety in the reverse chain (Ghiassi and Spera, 2003; McFarlane and Sheffi, 2003), these vertical data sets do not give insight into the life or use of a product - valuable data for processing and servicing returns. The potential exists for rich data flows from the consumer to business (C2B), such as how the product was used, expected time of return, volumes and condition of the product, which may inform and affect reverse exchanges. Using IoT applications, it is possible to negotiate with consumers to gain access to their data and, hence, gain visibility into value creating practice in the home.

\subsection{Visibility}

Visibility in supply chain management is commonly characterised from the perspective of information, that is, the exchange or sharing of information, the properties of the information exchanged and the usefulness of the information exchanged or the capability of firms to act on the information exchange. The literature that supports these different perspectives are presented in Table I, which adapts and builds on classifications used in previous work (Caridi et al., 2010, 2013; Klueber and O’Keefe 2013).

The studies in Table I are concerned with data that provide information from other businesses and are used in optimising processes related to $\mathrm{B} 2 \mathrm{~B}$ relationships. None of the work addresses or gives examples of the visibility of the use of a product by a consumer within their context, such as in the home. Visible data flows currently available to providers relating to consumers draw on point-of-sale (PoS) information or consumer survey data (Kiely, 1998; Croson and Donahue, 2003). PoS data capture patterns of when consumers acquire goods and services, but not how they use those purchases to achieve their goals or their post-consumption practices of recycling, disposal or dealing with failures that might result in returns (O'Cass and Ngo, 2011). Survey data are often used to enhance knowledge of how a product/service is used (Weber and Kantamneni, 2002; Bustinza et al., 2013). Survey captures stated preferences and contingent valuations, but hypothetical bias means respondents tend to overestimate the value they place on a product or service which can lead to over-investment by firms (Blomquist et al., 2009).

In $\mathrm{B} 2 \mathrm{~B}$ markets, the access to earlier information that signals the forming of a need allows the provider to manage its supply chain in sync with evolving consumer demand. As a guide to the potential of $\mathrm{C} 2 \mathrm{~B}$ data, we can examine the literature on B2B interactions to identify three important points: the fit of visibility information, the fit to operational purpose and the visibility of context of use of the offerings.

The fit of visibility information to the information structure of the provider's supply chain focusses on value-in-use and implies knowledge of processes, rules, practices and interactions of other entities, including the customer. For example, the act of making tea requires access to a tap, a kettle, cups, milk and perhaps sugar. In the reverse supply chain, we may see waste water, tea bags for disposal and cups for cleaning. A closed loop supply chain supporting tea making would need to ascertain what data from the combination of different sub-processes would be useful, how it can be captured and formatted so it is accurate, trusted, timely and can be integrated into the provider's supply chain (Bailey and Pearson, 1983; Gustin et al., 1995; Mohr and Sohi, 1995; Closs et al., 1997; Whipple et al., 2002; Barratt and Oke, 2007).

Second is the fit to operational purpose of the supply chain. Some providers do not have complex supply chains, and they optimise to respond to customers on demand. In such cases, visibility is simply data on when an item is running out. However, other supply chains may be more complex, for example, where the supply chain integrator does not directly control all of its supply chain. In the more complicated case, there are different data requirements (Caridi et al., 2013) which need to match to the operational purpose and capability of each provider.

Finally, visibility of the context of use of offerings can affect the production of the offering. Greater visibility may lead to modification of the design or the postponement of production within the supply chain to achieve agility, customisation and

Table I Alternative characterisations for visibility

\begin{tabular}{|c|c|c|}
\hline Visibility is & Focus placed on & Sources \\
\hline $\begin{array}{l}\text { Access and use of information across a supply } \\
\text { chain }\end{array}$ & Information exchange or sharing & $\begin{array}{l}\text { Lamming et al. (2001), Bradley (2002), Swaminathan } \\
\text { and Tayur (2003), Schoenthaler (2003), Simatupang } \\
\text { and Sridharan (2005), Francis (2008), Vitasak (2013) }\end{array}$ \\
\hline $\begin{array}{l}\text { Determined by the extent to which the shared } \\
\text { information is accurate, trusted, timely, useful } \\
\text { and in a readily usable format }\end{array}$ & Properties of exchanged information & $\begin{array}{l}\text { Bailey and Pearson (1983), Mohr and Spekman } \\
\text { (1994), Gustin et al. (1995), Mohr and Sohi (1995), } \\
\text { Closs et al. (1997), McFarlane and Sheffi (2003), } \\
\text { Chan (2003), Barratt and Oke (2007), Caridi et al. } \\
\text { (2010, 2013), Francis (2008), Dittmann (2006), Goh } \\
\text { et al. (2009), Zhang et al. (2011), Klueber and } \\
\text { O'Keefe (2013) }\end{array}$ \\
\hline $\begin{array}{l}\text { A capability that brings attention to } \\
\text { exceptions in supply-chain execution (sense) } \\
\text { and facilitates action (respond) }\end{array}$ & $\begin{array}{l}\text { Capability to use information to initiate and } \\
\text { inform action }\end{array}$ & $\begin{array}{l}\text { Eisenhardt and Martin (2000), McCrea (2005), Kaipia } \\
\text { and Hartiala (2006), Barratt and Oke (2007), Caridi } \\
\text { et al. (2010), Wei and Wang (2010), Holmstr\&ouml; } \\
\mathrm{m} \text { et al. (2010), Klueber and O'Keefe (2013), Soh } \\
\text { et al. (2011) }\end{array}$ \\
\hline
\end{tabular}

Source: Adapted from Caridi et al. (2010, 2013); Klueber and O'Keefe (2013) 
Operationalising lot for reverse supply

Glenn C. Parry, Saara A. Brax, Roger S. Maull and Irene C.L. Ng
Supply Chain Management: An International Journal

Volume $21 \cdot$ Number $2 \cdot 2016 \cdot 228-244$ dynamically reconfigurable context-appropriate offerings (Holmström et al., 2010; $\mathrm{Ng}, 2014$ ).

In B2B markets, quantitative data on visibility of use are achieved in the industrial IoT as a part of engineering contracts via health and usage monitoring systems (HUMS) (McNaught and Zagorecki, 2011, p. 276; Esperon-Migueza et al., 2013). Such systems use sensors to monitor the operation of equipment, such as cycle times, flow rates, consumption, wear rates and operating environmental conditions such as temperature, humidity, etc. The sensors provide condition-based maintenance data, which facilitate prognostic modelling for service provision in complex services. Visibility of the use of an offering removes much of the risk of asset support created by variability in the user demand for provider support, as evidenced in B2B markets supporting complex engineering products (Davies, 2006; Johnstone et al., 2009). An often cited example of such a service is the "power-by-the-hour" constellation of services between Rolls-Royce and aviation customers (Davies, 2006 and Johnstone et al., 2009). The use of such systems has affected product and service process design (Jagtap and Johnson, 2011), facilitating the move by manufacturers to gain revenue through service provision, a transition named "servitization" (Baines et al., 2009; Vandermerwe and Rada, 1988). However, within these contracts, beyond sensor data, there is little sharing of contextual data to explain the "why?" of operations or reveal client aspirations and fears within the contractual relationship (Mills et al., 2011). In the B2C literature of home sensor data, the focus has been on assisted living for the elderly or impaired and does not directly address the potential commercial benefits for shared data in reverse supply chains, which is the potential we address (Wilson et al., 2005; Majeed and Brown, 2006; Ding et al., 2011; Monekosso and Remagnino, 2013).

\subsection{Value and the measure of use in context}

Supply chain management aims to lower the cost and enhance the value by managing relationships with suppliers and customers (Christopher et al., 2002, p. 2). Interlinking domestic consumer and provider processes are described as service encounters (Payne et al. 2008, p. 92) or episodes (Ravald and Grönroos, 1996). Both encounters and episodes are opportunities to collect data about the consumer's process at specified points of exchange or interaction. Traditional supplier-centric approaches focus on data from the point of exchange encounters, for example, retail PoS data, and either ignore "the unseen" consumer domain or seek to capture detail via surveys.

Marketing literature has proposed that one way for an organisation to innovate is to focus on the concept of value in use (Penrose, 1959, p. 25; Ng, 2014; Vargo and Lusch, 2004, 2008). These authors emphasise the importance of consumer value-in-use over measures of value that are too firm centric (Ravald and Grönroos, 1996; Ng, 2014). Value-in-use can be viewed as only being realised during the experience of a market offering (use) within a specific time, place and setting (context) (Vargo et al., 2008). Providers of goods and services seek to meet the needs of their consumers through their offerings delivered in a timely manner. Yet to know the potential and expected value-in-use, suppliers need information about how and when their offerings are required and why they are used as part of consumer use processes.

The IoT brings major technological change that has the potential to provide significant data and provide visibility as to consumer product usage (Vermesan, 2011). At the heart of the IoT is the concept that every "thing" in the world could be connected to the Internet; for example, each power socket in the home will have an IP address to enable data to be collected on connected equipment and power use (Cerf, 1997). It is possible to gain insights beyond single supply chains and gain visibility into contexts of use, as the IoT vision is not restricted to devices. Connecting social media with things and integrating social media data such as calendar functions, personal blogs and Facebook with IoT functions (Albrecht, 2013 \#4989) allows the integration of information from multiple platforms (Gubbi et al., 2013; Atzori et al., 2010). The IoT provides opportunities for a new class of services (Miorandi et al., 2012) and opportunities to extend the supply chain by using the data to create greater visibility of the consumers' lived lives, planned and actual use of resources in combination, with and for people. As more things are equipped with sensors and have IP addresses, more data are available on their action and through analysis; the interactions between things and their use in context can be understood (Nikander et al., 2013 \#3585). In short, IoT provides the potential for data to be collected on the experience of a good or service (use) within a specific time, place and setting (context).

Literature on the use of IoT technologies to facilitate supply chain management has focussed extensively on B2B solutions (see the IoT Supply Chain special issue by Zhou et al., 2015) and single vertical supply chains (Pang et al., 2015). Existing systems collecting C2B household data for providers are proprietary systems designed to support a particular service from a single provider/vertical supply chain, such as water and electrical meters and data from a supermarket delivering goods to the home. Data are "taken" from the consumer and used by the provider. C2B sensor data, using wireless sensor networks, are used in healthcare for remote patient heart rate and blood oxygen monitoring and in logistics to sense if packages are damaged before customer delivery (Umar, 2005, p. 10). These examples do not use more than one vertical supply chain and do not give context of use, antecedents or precedence.

\subsection{Identification of use-visibility measures from consumption processes}

Combining the understanding of consumption and context from marketing literature with the availability of IoT data, we seek to understand visibility of the consumer use processes practice by capturing both process and data flows through a model of the system. There are a number of methodologies that support the representation of processes involving products and information, for example, VSM[2], BPMM[3], COMET[4] and IDEF0[5]. Of these methods, we propose IDEF0 is appropriate, as it tells the story of what happens in the system (Perera and Liyanage, 2001) by describing processes as series of activities linked via input and outputs, constraints and support mechanisms. IDEF0 can model the data flow, functional flow and process, and by combining multiple social and sensor data streams, it can tell the story of 
value creation (NIST, 1993). Figure 2 shows the generic IDEF0 model.

The IDEF0 approach structures four components of a transformation function, where the function is described using a verb in a box (NIST, 1993). For the purpose of this study, the function is the creation of "value-in-use". Resource inputs and outputs are data or objects. Inputs enter the box from the left and are transformed by the function and exit the box to the right as outputs. Control enters at the top of the box and has influence or determines the function performed, whilst Mechanism refers to the static facilitating resources used to undertake a function (Kusiak, 2002; Aguilar-Savén, 2004). Typical data groupings for inputs in manufacturing and maintenance are parts measured as units (arrival patterns, schedule data, bills of materials), resource data which are defined by product or process specification (breakdown data, operator allocation, set-up times, process times) and the routing information to draw the mapping (priority, process routes) (Perera and Liyanage, 2001). Within the supply and consumption literature, demand is examined using PoS data. The measures recorded in PoS data include identification of the sales clerk, date, time and product data from the bar code which includes product details, the units sold, packing type, ingredients, etc. (Matsko, 2005). PoS is used in conjunction with electronic data interchange (EDI) technologies to ensure that stock holding is not depleted below a level which matches forecast and creates sales data and shipping notices (Williams and Waller, 2011).

The measures (input/output) are for inventory management and could be described as monitoring depletion. Offerings that deplete from the perspective of the local stockholder are unit products, and the visibility of depletion can be understood based on the time and location of the item and the quantity before and after sale (Weber and Kantamneni, 2002).

In contrast to the unit of stock, input/output resources, such as utilities electricity, gas or water, which are also measured in units are delivered via pipes or cables. There are very different supply chain considerations focussed upstream on efficiency to deliver downstream cost saving, as the product is subject to little processing or alteration during its lifetime in the supply chains (Smart, 2005; Halldórsson and Svanberg, 2013). These are offerings that are consumed and replenished at the rate of consumption from the end user/domestic perspective, hence can be considered as consumption items.

Another form of input that is durable, such as crockery and towels, can be described as experienced and transformed, but

\section{Figure 2 The generic IDEF0 model}

IDEFO

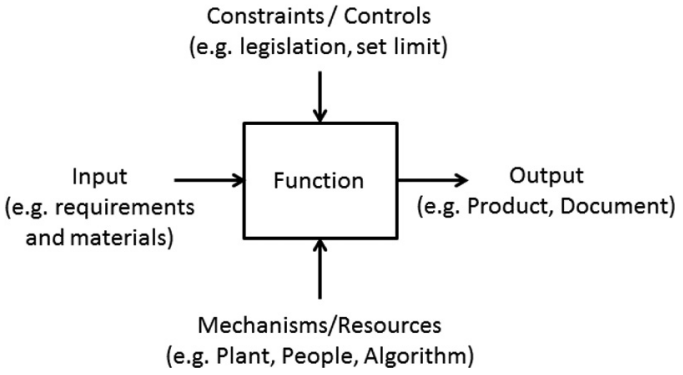

not consumed during use by the consumer. The input may be diminished but not necessarily depleted or consumed during a single use and so, as with condition-based maintenance, resource measures are based on time, number of uses, location and use environment.

Mechanisms or resources are typically people, systems or machines; they enable the function but are not transformed by it. The measure reflects an interaction, and a mechanism may change in state, but it is not markedly diminished during normal use. Domestic examples would be ovens, fridges, TVs and taps. As with experience measures, the visibility of interaction can be understood in terms of condition-based monitoring measures: number of uses, time, location and environment; the state of the physical product with each interaction (e.g. turned on/off); and the introduction of other objects into the offering, for example, placing toast into the toaster.

Summarising this discussion, we propose four categories which we name UVMs for the study of use processes in the context of home: Depletion measures relate to products which reduce in quantity in local stock holdings when used. Consumption measures relate to resources which are replenished at the rate of consumption. Experience measures relate to resources which are diminished but not depleted by a single action, but are diminished by multiple uses. Interaction measures record the use and environment of a mechanism.

In the following case example, the categorisation of UVMs is used to group in the case study homes. We argue that the four measures form a substantial part of the data requirement in understanding consumer use processes for SCV.

\section{Research methodology}

\subsection{Research design}

The study is based on an explorative case approach. Case study is defined as an empirical enquiry taking place at the real-life context of a contemporary phenomenon, for which the boundary between the phenomenon and its context is difficult to clarify (Yin, 1994). Qualitative case research designs are used for research problems that need to be researched in situated spatial and temporal contexts that preserve the social character of the complex configurations of structures and events (Dubois and Araujo, 2007). In the study of information systems, interpretive research is considered helpful, as it facilitates the understanding of human thought and action in social and organisational contexts and, consequently, the development of deep insights concerning information systems phenomena (Klein and Myers, 1999). The use processes of consumers are such socially bound phenomena; the sensors provide information about simple parameters, but the individuals involved can give interpretative meaning that connects the units measured into a use process.

As pre-existing research on the use of IoT is scarce and the use context is an emerging phenomena of study, the research takes an explorative and developmental approach. Explorative case studies begin with a "clean theoretical slate" and specified constructs and without predictions of theory or rival theories (Dube and Pare, 2003). As the research objective is to understand the consumers' use behaviour at home, performing the research "in the field", that is, in the context of 
the home, provides the most authentic setting for generating new theoretical frameworks.

Due to the nature of our problem domain, that is, how can Io $T$ increase the visibility of consumer use processes to create data to inform reverse supply chains, the study combines both qualitative and quantitative data. The role of the quantitative data generated by the sensors is to provide simple, objective information about the measurement points located in the use context. The role of the qualitative data is to connect these measurement points into a use process. This provides meaning and background information that are useful in explaining the observed quantitative patterns and provide a validity check and feedback to the researchers. This is particularly useful in this type of explorative study, where the research process is iterative, moving between the technical design of the test environment and progress of analysis. Illustratively, Dube and Pare (2003) have termed this characteristic of explorative analysis as a "flexible and opportunistic process".

The empirical data used in this research has been collected from a sample of six UK households which includes families and single people. Household occupants' ages range from 5 to 65 years. The home-owners gave informed consent to the studies to access their data.

\subsection{Data collection}

\subsubsection{Sensors and systems}

The units of analysis in the study are the consumers' use processes in the home. Sensors and systems were installed in the studied six homes to collect data and to store it on a personal data platform (PDP). A Fibaro Home Centre2 (Fibaro.com) was used as the platform to collect data from $\mathrm{Z}$-wave devices and sensors, which are then exported via APIs and saved in a database. Z-wave is a wireless protocol supporting small low-power devices and sensors, which are relatively cheap, simple to retrofit and have a long battery life (PACE, 2007). The $Z$-wave sensors used were motion sensors which included accelerometers, temperature and lux (light level); lighting controllers/switches; door and window sensors, which recorded open/closed state, which could also be used to detect when an item is moved away from its storage position; power on/off relays; and water sensors. Two Wi-Fi connected devices were created specifically for the project. A smart cabinet named "Auto-magic Beauty Box" (AMBB) tracks the rate of consumption of consumables placed within it using weight linked to the bar code of the item (Oliver, 2015). The second is a Wi-Fi-enabled toilet roll holder (Speed and Barker, 2014) using an infrared sensor to detect consumption. Google Calendar and Outlook Calendar were used to collect data on individual schedules.

\subsubsection{Qualitative data}

Ethnographic style data collection was undertaken to analyse the impact on behaviour, ethical and cultural implications of monitoring (Luger and Speed, 2014; Speed and Luger, 2015; Tolmie et al., 2016). The ethnographic approach involved a visit to the user's homes, a session with each home owner and, where appropriate, their family. Sensor-generated data were supplemented by user diaries and additional interviews to explore the meaning of the quantitative data and to validate the accuracy of assumptions and correlations. To enable further in-depth analyses, the users wrote detailed descriptions of the way functions were enacted in their home, the resources they held and used, with particular focus upon three case activities: showering, breakfast and activity in the house between 7 and $9 \mathrm{pm}$. The showering process was selected as the exemplary use process discussed in this paper. The conceptualisation of the UVMs was developed using an abductive analysis process, in which the data from the cases were compared and later contrasted with the pre-existing concepts from the literature (Aaboen et al., 2012; Dubois and Gadde, 2002). The resulting framework was, then, used for categorisation of the findings.

\subsubsection{Unit of analysis and mapping}

In this paper, we focus on the "showering function" as the exemplary use process that illustrates the concept of operationalising visibility measures in the home. The case example of showering is based on one shower room from the six households, and it contains a toilet, shower and sink and is the locus for different personal hygiene activities; in this case, the unit of analysis focuses on the showering activity. Whilst the current study chooses the showering as the illustrative case, the usability of the UVMs as a concept is not limited to the showering use process. Similar IoT instrumentation, data collection and analysis could focus on any other typical episode taking place at home, such as cooking or cleaning. As a case example, the showering activity is purposeful for illustrating the potential of UVMs, as it is relatively simple and easy to comprehend.

Showering is a multi-step activity during which consumers use a wide range of different resources to complete the process. Showering is an activity which is private to individuals, there are typically no digital devices used, video cameras are not acceptable and the main power supply use is limited due the potential dangers with water. Z-wave sensors are appropriate for use in this space, as they are battery powered and, therefore, do not present a hazard to the user. The AMBB records depletion, as the resources are stored in the box and measured before and after use. IDEF0 mapping was used to capture the process flow, and following best practice, levels of detail and systems boundaries were set by the analyst and the choices were reviewed by two other researchers (Boucher and Yalcin, 2006, p. 127). In determining the system boundaries for the support mechanism, only the items which are active in the process were included. In the shower case, this includes the light and extractor fan which turn on when someone enters the room. Collected data for the exemplar case show that the light source is a $11 \mathrm{~W}$ bulb and the extractor unit present is of $0.5 \mathrm{KW}$ and that both light and extractor come on together. The shower system includes the fixtures and fittings such as taps, doors, screens, plumbing, etc. Though outside the scope of this paper, each part of the showering mechanism could be considered separately and the model decomposed further, a process facilitated by the IDEF0 mapping technique.

\section{Case analysis and results}

To empirically illustrate the operationalisation of IoT technology in the home, the case example we give here provides details of the resources and specific IoT 
instrumentation used in our case households. Initially, the participants inventoried all the contents of their bathroom, which created an extensive list of resources. The ethnographic style data captured their behaviour and use of the resources. Resources were categorised according to the nature of how they were used, and appropriate instrumentation of each resource allowed us to capture the use data. Data collected from the six case study households were used to create a composite single exemplar case for use in this paper. These are classified into the UVM categories (Table II), and the resources used during showering activity are underlined.

All the depletion resources are measured using the AMBB. Consumption resources are measured using two $\mathrm{Z}$-wave sensors, one detecting when lights are on and the other when water is flowing. We capture data from experience using accelerometers which indicate the movement of an object. Interaction was captured using direct sensor measures, such as movement, door open/closed, etc., or taken as a secondary measure - for example, water in the shower indicates that there has been interaction with the shower tap. Data collected at the point in time of "showering" give the set of data from across the UVMs, providing information that would normally be held by multiple firms, for example, power provider, retailers, water provider etc. The data illustrate the preferences for products used and how they are used in combination. Mapping the shower activity and drawing on exemplar data from the sensors and ethnography of the DP0s, we can construct the generic shower room activity in an IDEF0 map.

In Figure 3, a model for a shower function is shown, with the system boundary around the shower activity and the outputs which enter reverse supply chains. In this case, processes other than showering are not considered. The constraint to the shower process beginning is an individual; in
Figure 3 IDEF0 model for "Megan's shower"

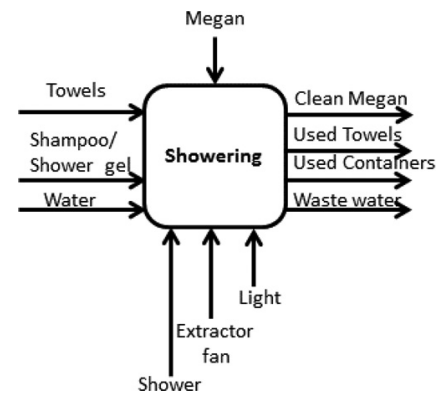

the case example, we have named her "Megan", who will be transformed in the function to output Megan in a "clean" state. The measure of "clean" is a perception of the individual, and it is not appropriate or necessary to instrument, as the individual has the agency to decide this themselves. The case shower mechanism uses main water pressure through a mixer tap that has a thermostat fixed at $38^{\circ} \mathrm{C}$; the accuracy was confirmed using a thermometer. Water flow rate was measured at 7.751 per minute, slightly under that stated by the manufacturer, that is, 8.1 per minute.

Data show that the operating temperature in the room holds at a constant of approximately $24^{\circ} \mathrm{C}$ (similar relatively static temperature measures over time are seen in multiple case study shower rooms), a light level of 134 lux, when light is on and 0 if it is off, as the room has no window. The marked change in the environment was that of humidity, which is high during showering and remains high immediately after showering. Humidity change is shown in Figure 4 for a two-week period. Note that sensors only report changes in humidity, hence the non-linear $x$-axis. The data give environmental information

Table II. Resources in the bathroom categorised by use visibility measure

\begin{tabular}{|c|c|c|c|}
\hline Depletion & Consumption & Experience & Interaction \\
\hline $\begin{array}{l}\text { Toothpaste (in use) } \\
6 \times \text { new toothbrush } \\
2 \times \text { toothbrushes (in use) } \\
\text { Mouthwash } \\
\text { Hand soap } \\
\text { Hair product } \\
\text { Moisturiser (face) } \\
\text { Moisturiser (eyes) } \\
\text { Cleanser } \\
\text { Toner } \\
\text { Shave gel } \\
\text { Razor blade (in use) } \\
2 \times \text { boxes new razor blades } \\
\text { Deodorant } \\
\text { Shampoo } \\
\text { Body wash (female) } \\
\text { Shower gel } \\
\text { Mud mask } \\
3 \times \text { cold medicine (new) } \\
2 \times \text { dental floss (new) } 3 \times \\
\text { toilet roll }\end{array}$ & $\frac{\text { Water }}{\text { Electricity }}$ & $\begin{array}{l}2 \times \text { hand towel } \\
2 \times \text { bath towel } \\
\text { Flannel } \\
\text { Razor handle }\end{array}$ & $\begin{array}{l}\text { Sink } \\
\text { Sink hot and cold taps } \\
\text { Shower door } \\
\text { Shower tray } \\
\text { Shower mixer taps } \\
\text { Shower head } \\
\text { Shower rail } \\
\text { (Adjustable) } \\
\text { Mirror } \\
\text { Toilet } \\
\text { Light switch } \\
\text { Wall lights } \\
\text { Ceiling lights } \\
\text { Extractor fan }\end{array}$ \\
\hline Note: Underlined resource are & e example & & \\
\hline
\end{tabular}


Figure 4 Environmental change (humidity over time) of shower room

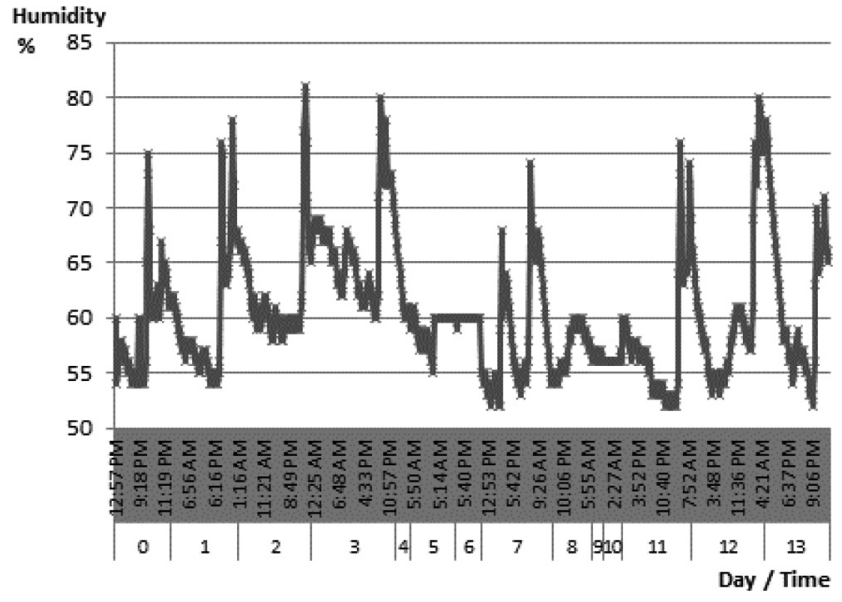

relating to the context of use of a product during its life in the home. The products in the shower room are exposed to a warm and humid environment, which is usually dark; these lifetime data are useful in decision-making with regards to products entering reverse supply.

The mechanism is not altered as a result of the single transformation event but will be altered by multiple transformations, and after many cycles, certain parts or all of it may enter the reverse supply chain for recycling, reuse or waste disposal. Data are available to inform the mechanism providers. For example, the producer of the tap could access the environmental operating conditions of the mechanism, number of cycle times, water pressure and flow rates and could ask the consumer to provide such data to see how long their mechanism lasted in a given environment.

The inputs to the system are identified in ethnographic studies, where DP0s were asked to write a short description of their shower process. The common inputs were water, shower gel, shampoo and a towel. Water use is measured using the flood sensor to indicate when the shower is on/off. As time and volume per minute is known, total volume of water used can be calculated. Both shampoo and shower gel are calculated by measuring the weight difference of the bottle before and after use, thus negating the need for electronics in the shower. Interviews found that shampoo is usually used by an individual, but shower gels/soaps are often shared.

Figure 5 shows two weeks of shower data, giving the duration of the shower and the water volume consumed. From the figure, it can be seen that Megan showers every day with average shower length of 19 minutes, with a standard deviation of 5.3 minutes. Her longest shower was 29 minutes and shortest was 12 minutes. Her average shower uses 149 litres of water, with a maximum of 224.1 and minimum of 93.1. The data also provide information as to the use duration of the mechanism and its sub-systems; for example, each shower represents a cycle of use for the taps, shower doors, etc. There was no visibility of shower duration to the user during the experiment, and when presented with the actual data, "Megan" was surprised by the duration of showers, stating "I thought I only took 5 minutes".
Figure 5 Sample of 14 shower events, with "Time in Shower" (primary Y-axis) and "Volume of Water" on secondary Y-axis

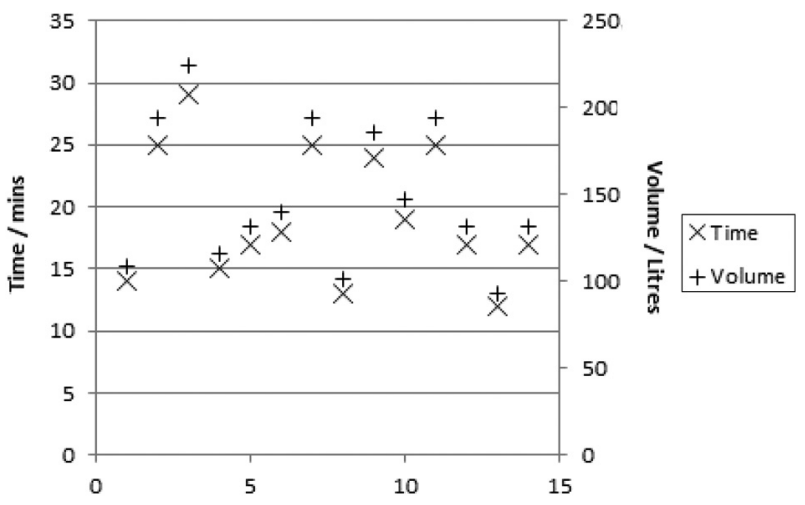

The IDEF0 shows that the shower activity is enacted with the material resources: towel, shower gel and shampoo. Data of depletion of a single bottle of shower gel over two weeks duration are in Figure 6. The bottle of shower gel is shared between two people, Megan and her partner, who both use it daily. Depletion approximately doubles if Megan has been running, and shower time increases. The trend line suggests that $20 \mathrm{~g}$ of shower gel is used daily, but despite the $R^{2}$ being approximately 0.9 , this is erroneous. Sensor data are supplemented with information from diaries which explains the changes in values observed. The average data are affected by an incident where the couple's dog knocked over the bottle of shower gel, causing a wastage of approximately $84 \mathrm{~g}$. Removing the spillage from the data, the new depletion calculated reduces the average to approximately 4 g per shower.

Figure 7 presents an example of depletion data for two shampoo bottles of equal volume, with data presented for 122 days, from 1st February to 15th June 2015, which captures the depletion of two bottles. The shampoo was only used by Megan. With this data set, there is some noise and slight "drift" due to the sensor and the AMBB box being a prototype, making precise measurement of daily depletion inaccurate. It is not possible to make any specific comments on an individual day's depletion, but the linear fit $R^{2}>0.9$ shows that the average measure is valid and significant. Average depletion rates are (A) $2.32 \mathrm{~g}$ and (B) $2.25 \mathrm{~g}$ per day.

Figure 6 Depletion of shower gel

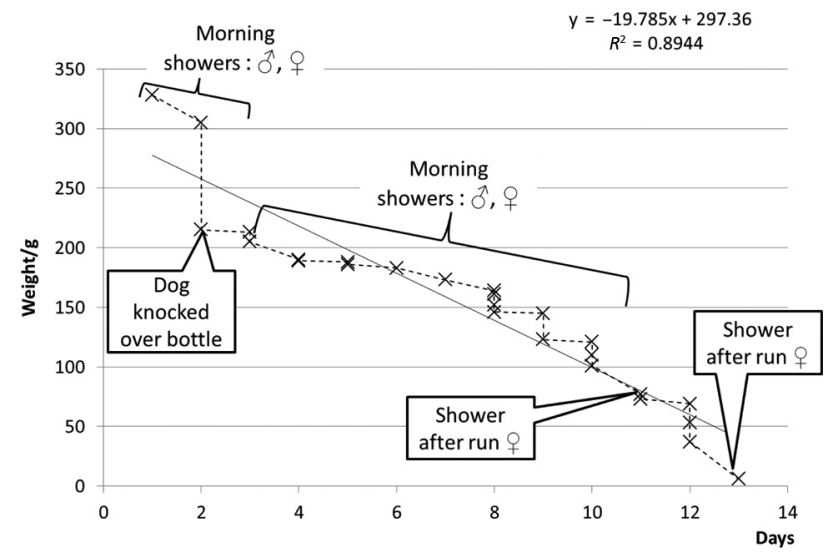


Figure 7 Depletion of shampoo

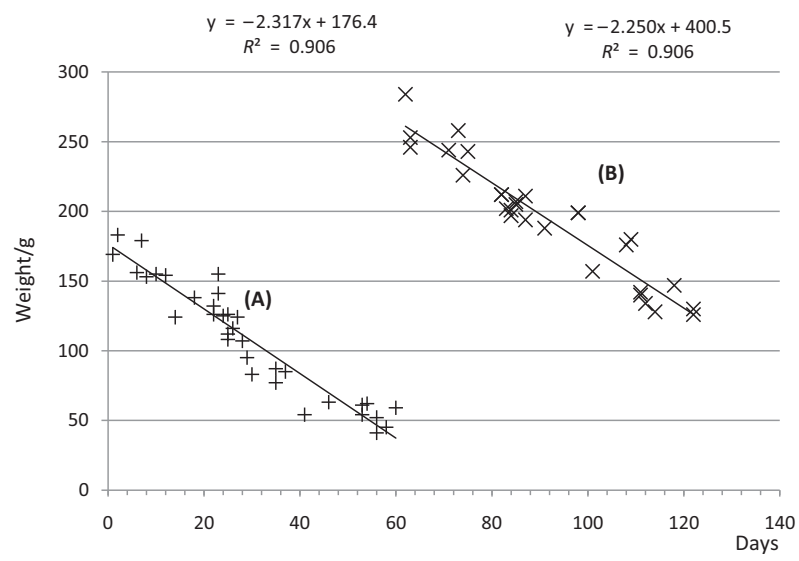

There were no significant events (e.g. holidays, visitors, etc.) which disturbed the regular pattern, and hence, the depletion is linear. However, variance in the total days for the bottle to be used is observed. Bottle $A$ lasted for 59 days and Bottle $B$ for 63 days. On average, a recycler may expect a bottle every 61 days, but this neglects that there is a difference of 4 days between maximum and minimum values.

The towel use is monitored by using a PIR motion sensor and an accelerometer that sends a signal if the towel is moved. Megan uses one large towel for showering which she stated is "hers" and is not shared with others who use the bathroom, as other hand towels and bath towels are available. Present towel "condition" was assessed by Megan, though towels were washed every two weeks regardless of the use as that was her "process". The sensor data showed that the towel was used multiple times every day, often for very short periods. From the data and discussion with Megan, it was found that the towel was located on a hook next to the sink, and it was apparent that others were using her towel for hand drying.

The explorative case analysis documented above shows how IoT devices can be implemented to track consumers' use processes of goods, services and resources in their homes. Despite its limited scope, the case analysis illustrates issues that are of interest to reverse supply chains. First, consumer's perceptions of resource use can significantly differ from the actual use. The sharing of towel without Megan's knowledge and the difference between the time spent in shower versus her own assessment are aspects of this. Second, use processes that are connected can follow different patterns, meaning that some use activities are moderators for other use processes. For example, when Megan goes running (moderator), she uses twice as much shower gel and water. Third, consumption processes in the home are partially shared by the residents. When the generated data represent the individual in shared spaces, attribution of data to an individual becomes more complicated than when accumulating data from personal devices, such as smartphone applications.

\section{Discussion and conclusions}

The case shows that current technology enables access to real-time consumer data beyond the point of sale, though commercial platforms are not yet widely adopted and need further development. Extended to the use of goods and services with longer life cycles, such data would enable firms to develop new approaches and business models to improve both forward and reverse supply, possibly extending collaborative supply chain constellations from B2B asset maintenance to consumer context. IoT applications could enable "orderless inventory replenishment" for consumers, combined with new product delivery and waste collection solutions.

The case study provides an illustrative example of operationalisation of IoT to capture consumer use of an offering in context. The case demonstrates the collection of data associated with a function, in this case showering, which is the value-in-use process of the consumer and acts as a proxy for any encounter or episode (Payne et al., 2008, p. 92; Ravald and Grönroos, 1996). Individual data sets from the vertical supply chains are shown, but it is only when visibility of all the resources are brought together that the context of use of the resource becomes visible.

Our study proposes four UVMs and empirically demonstrates how they can be operationalised in a way that can contribute to SCV. We present how the UVMs can provide accurate and timely information which can be used in supply chain exchanges to optimise flows and eliminate waste (Lamming, 1996; Lee, 2000; Simatupang et al., 2002). We propose that UVMs constitute the event data necessary to inform the primary reverse flow in the future supply chain. This makes consumer more than just a point of stock holding for a product (Wells and Seitz, 2005); we now have data that recognise the consumers agency and processes when in possession of the product. The case study operationalises UVM depletion data for products which, in combination with the antecedents to showering, gives much better indications as to when, for example, the owner's empty containers are going to enter the reverse supply chain. Extending this across multiple home activities would provide a full picture of waste and recycling.

The context of use data challenges the dyad of efficient or responsive return processing (Fisher, 1997; Blackburn et al., 2004), facilitating the analysis of condition and potentially removing the need for either centralised or multiple returns centres. Using UVMs to inform exchanges in reverse supply would potentially lead to gains in efficiency and responsiveness. UVM data indicate cycle number and cycle time for showering and detail of the operating environment of the mechanism and resource, such as humidity, light level and temperature - all variables that can lead to the rapid deterioration of products (Vargo and Lusch, 2008; Gummesson and Mele, 2010; Edvardsson et al., 2014). UVM provide indicators as to the context of operation for the life of mechanisms which, if made available, can contribute to the inspection and reverse supply decisions on repair, warranty claim, potential reuse and product routing for recycling or landfill (Santibanez-Gonzalez and Diabat, 2013).

The example highlights environmental benefits, as in this case shower activity creates on average 149.1 of waste water which contains only small quantities of contaminant; $4 \mathrm{~g}$ of shower gel; and $2.3 \mathrm{~g}$ of shampoo along dirt; etc., from the user. These are data which may be useful for water treatment works or indicate its suitability for reuse (WaterWise.org.uk). UVM experience data give the provider visibility of the assets 
use, and hence, the opportunity to enhance the value in use for the consumer (Ravald and Grönroos, 1996; Vargo et al., 2008). Such data may influence the design of the offer, changing frequency that items experienced by consumers are maintained, the location of the resource or quantity provided.

Our study integrates the understanding of value-in-use and consumption literature from marketing into reverse supply chain management. By logically applying the understanding via an IDEF0 framework, we propose four sets of UVMs available through IoT data - that of experience, consumption, interaction and depletion. Measures are operationalised by monitoring households with IoT sensors, capturing data and demonstrating the data's relationship and potential impact on the exchanges in reverse supply chains. From the work, we identify four key elements of reverse supply that visibility use measures impact.

\subsection{Design potential touchpoints for product acquisition}

Understanding visibility helps firms in creating new touchpoints with consumers for product acquisition, a key component of reverse supply (Guide and Wassenhove, 2002) (product acquisition in this sense refers to acquiring the right product in sufficient quantities and at the right price for reverse suppliers involved in activities, such as recuse, repair, recycling, etc.). Access to visibility data enables providers to better understand the process through which the product is used and reasons it may have failed, for example, the location, timing and event and their various combinations that trigger the products entry into the reverse supply chain. We can envisage a situation where IoT devices may automatically transmit these data alongside a request to pick up the failing product prior to the fault development, facilitating firms engaged in product acquisition. Consumers and reverse suppliers may be better guided as to the end of use options: resale, exchange, take back and scrap (Govindan and Popiuc, 2014).

\subsection{Improve timings of reverse supply}

Second, the visibility of use allows firms to investigate the timing of product returns. Managing capacity in a highly uncertain environment is one of the most fundamental problems of operations management, leading to increased costs and a poor use of resources. Data that improve the predictability of returns and service requests will help not only the product manufacturer but also logistics service companies (Srivastava, 2008). In large-volume consumer markets, this offers the potential for considerable efficiencies through improved capacity management and planning, as well as through synergies in processing the goods. This increase in efficiency should lead to sustainability gains by increasing recycling of materials and reducing emissions.

\subsection{Use customer resources to increase the efficiency of reverse supply}

Understanding visibility would help firms consider how customer resources can help firms with reverse supply. For example, inspection and reconditioning are parts of the costs of a reverse supply. Through an understanding of use and having greater visibility of consumption, firms could incentivise consumers to pre-inspect or dispose parts of the product, so that the firm can have a more effective reverse supply. Using customers as agents of the firm is an extension of the concept of customer as employee (Johnston, 1989), which recognises that customers can be selected, trained, motivated and even dismissed and raises the issue of design and management of the customers role.

\subsection{Improve coordination and closed loops}

Availability of use-visibility data enables firms to systematically analyse and understand the variety of relevant consumption contexts and how firms could manage how this variety affects their reverse supply chains. For example, establishing types of pattern of use will provide much richer data sets, which in turn reduces uncertainty during sorting and diagnostic processes (Guide et al., 2000). This may also enable a fundamental change in the evaluation activity challenging Blackburn's et al. (2004) trade-off between efficient and responsive chains and changing the decision variables for establishing the location of the product return evaluation activity.

\section{Managerial implications}

IoT data captured could significantly affect the efficiency and responsiveness of reverse supply by providing information of use in context, in addition to the real-time data on resource usage rates. It is well established that distortions in demand signals through the supply chain lead to: excessive inventory; poor customer service; lost revenue; poor use of capacity; inactive and inefficient transportation; missed production schedules (Williams and Waller, 2011). IoT data will help to mitigate these inefficiencies. For example, many toiletries (particularly sunscreen, dandruff products, etc.) now have an expiry date. Accurate data on usage will enable better signalling through the supply chain, reducing waste and transportation, lowering costs and reducing landfill. The financial models for this are as yet under developed but provide a significant potential for future research activity.

The benefits also extend to utility provision. For example, the costs of moving, treating and heating water in the USA accounts for $520 \mathrm{Bn} \mathrm{kWh}, 13$ per cent of US electricity usage (Mulligan, 2014). Data on utility usage also has significant potential for improving resource utilisation through smart grids, which will enable network operators to better use their infrastructures through real-time information and balancing generation patterns with demand patterns, with some estimates placing the economic benefits of smart grids between $\$ 1.3$ and $\$ 2$ trillion over 20 years.

IoT in the home also provides information on experience. In the case example of the bathroom context, these are towels, toothbrushes, shavers, etc. Experience data have the potential to help manufacturers produce bespoke offers, for example, in this case, towels for those with specific allergies or tooth brushes with specific head shapes and bristle type and alignment. Finally, there are also implications for interaction. For example, in the case study, sensors can detect calcium deposits on water systems and growth of moulds or freezing conditions that may lead to burst pipes. All of this offers the potential for asset manufactures to extend their offerings into service provision.

Io $T$ in the home also offers significant potential outside current business models, as horizontal data give information relating to how consumers use resources in combination, offering greater possibilities to innovate new offers, reducing 
environmental impact and enabling forward and reverse supply chains able to respond to use in context.

The rich data from IoT are owned by consumers, and negotiation for access to such data creates the basis for markets both for the raw data and applications which manipulate data for the benefit of consumers and firms. Such information is valuable to firms if they can trade with the consumer for access to that data, given appropriate respect for privacy, security and trust during the use of such data (Nissenbaum, 2004, 2011). Consumers with HAT-type platforms will effectively have ERP-like systems which could be integrated into supply chains, providing information which is significantly more detailed than that which has previously been conceptualised in the demand chain (Cambra-Fierro and Polo-Redondo, 2008; Bustinza et al., 2013). Engagement of the consumer through their data gives information of the actual consumption as opposed to PoS or survey data, which are indicative (Weber and Kantamneni, 2002). Significantly, the challenge of effective, responsive and efficient reverse supply is also met (Blackburn et al., 2004). The visibility of context of use reduces the uncertainty surrounding the volume of returns, knowing that volume allows for the better planning of the returns process. However, the ability to affect the reverse supply chain is limited to the extent that it is made available to multiple tiers and matches the operational purpose and capability of the provider (Caridi et al., 2013).

This study is limited in providing an example of a single-use context and much more research is needed, extending to various areas of domestic activities to fully realise the benefit of IoT in the home. The future challenge lies in how IoT data from many homes can be analysed such that outputs are useful and efficiently and effectively shared.

\section{Notes}

1 The Hub of All Things - HubofAllThings.com.

2 Value Stream Mapping - Rother, M., Shook, J., Learning To See: Value Stream Mapping to Create Value and Eliminate Muda, 1998 (The Lean Enterprise Institute: Brookline, MA).

3 Business and Process Model and Notation - bpmn.org.

4 Component and Model- based Development Methodology - COMET.modelbased.net.

5 Integrated Definition Methods - IDEF.com.

\section{References}

Aaboen, L., Dubois, A. and Lind, F. (2012), "Capturing processes in longitudinal multiple case studies", Industrial Marketing Management, Vol. 41 No. 2, pp. 235-246. doi: http://dx.doi.org/10.1016/j.indmarman.2012.01.009.

Aguilar-Savén, R.S. (2004), "Business process modelling: review and framework", International fournal of Production Economics, Vol. 90 No. 2, pp. 129-149. doi: 10.1016/ s0925-5273(03)00102-6.

Albrecht, K. and Michael, K. (2013), "Connected: to everyone and everything [guest editorial: special section on sensors]", Technology and Society Magazine, IEEE, Vol. 32 No. 4, pp. 31-34. doi: 10.1109/MTS.2013.2291170
Ashby, A., Leat, M. and Hudson-Smith, M. (2012), "Making connections: a review of supply chain management and sustainability literature", Supply Chain Management: An International fournal, Vol. 17 No. 5, pp. 497-516.

Atzori, L., Iera, A. and Morabito, G. (2010), "The internet of things: a survey", Computer Networks, Vol. 54 No. 15, pp. 2787-2805. doi: http://dx.doi.org/10.1016/j.comnet. 2010.05.010

Bailey, I.E. and Pearson, S. (1983), "Development of a tool for measuring and analyzing computer user satisfaction", Management Science, Vol. 29 No. 6, pp. 519-529.

Baines, T., H. Lightfoot, J. Peppard, M. Johnson, A. Tiwari, E. Shehab and M. Swink (2009), "Towards an operations strategy for product-centric servitization", International Fournal of Operations \& Production Management, Vol. 29 No. 5, pp. 494-519.

Barratt, M. and Oke, A. (2007), "Antecedents of supply chain visibility in retail supply chains: a resource-based theory perspective", Fournal of Operations Management, Vol. 25 No. 6, pp. 1217-1233.

Blackburn, J., Guide, D., Souza, G.C. and Van Wassenhove, L. (2004), "Reverse supply chains for commercial returns", California Management Review, Vol. 46 No. 2, pp. 6-22.

Blomquist, G.C., Blumenschein, K. and Johannesson, K. (2009), "Eliciting willingness to pay without bias using Follow-up", Environmental and Resource Economics, Vol. 43 No. 4, pp. 473-502.

Boucher, T.O., Yalcin, A. (2006), Design of Industrial Information Systems, Elsevier, Oxford.

Bradley, P. (2002), "How far can you see", Logistics Management, Vol. 41 No. 9, pp. 27-34.

Brody, P. and Pureswaran, V. (2015), "The next digital gold rush: how the internet of things will create liquid, transparent markets", Strategy E Leadership, Vol. 43 No. 1, pp. 36-41.

Brynjolfsson, E., Hitt, L.M., Kim, H.H. (2011), Strength in Numbers: How Does Data-driven Decisionmaking Affect Firm Performance?, available at: SSRN 1819486.

Bustinza, O., Parry, G. and Vendrell-Herrero, F. (2013), "Supply and demand chain management orientation: adding services to product offerings", Supply Chain Management: An International fournal, Vol. 18 No. 6, pp. 618-629.

Cambra-Fierro, J.J. and Polo-Redondo, Y. (2008), “Creating satisfaction in the demand-supply chain: the buyers' perspective", Supply Chain Management: An International fournal, Vol. 13 No. 3, pp. 211-224.

Caridi, M., Crippa, L., Perego, A., Sianesi, A. and Tumino, A. (2010), "Measuring visibility to improve supply chain performance: a quantitative approach", Benchmarking: An International fournal, Vol. 17 No. 4, pp. 593-615.

Caridi, M., Perego, A. and Tumino, A. (2013), "Measuring supply chain visibility in the apparel industry", Benchmarking: An International foumal, Vol. 20 No. 1, pp. 25-44.

Cerf, V. and Inton, G. (1997), When They're Everywhere Beyond Calculation, Springer, New York, NY, pp. 33-42.

Chan, F.T.S. (2003), "Performance measurement in a supply chain", The International fournal of Advanced Manufacturing Technology, Vol. 21 No. 7, pp. 534-548. 
Christopher, M.G., McKinnon, A., Sharp, J., Wilding, R., Peck, H., Chapman, P., Juttner, U. and Bolumole, V. (2002), Supply Chain Vulnerability, Report for the Department of Transport, Local Government and the Regions, Cranfield University, Cranfield.

Closs, D.J., Goldsby, T.J. and Clinton, S.R. (1997), "Information technology influences on world class logistics capability", International fournal of Physical Distribution $\mathcal{E}$ Logistics Management, Vol. 27 No. 1, pp. 4-17.

Cooper, M.C., Lambert, D.M. and Pagh, J.D. (1997), "Supply Chain management: more than a new name for logistics", International fournal of Logistics Management, Vol. 8 No. 1, pp. 1-14.

Croson, R. and Donahue, K. (2003), "Impact of POS data sharing on supply chain management: an empirical study", Production and Operations Management, Vol. 12 No. 1, pp. 1-11.

Davies, A. (2006), "Charting a path toward integrated solutions”, MIT Sloan Management Review, Vol. 47 No. 3, pp. 39-39.

DEFRA (2015), Digest of Waste and Resource Statistics - 2015 Edition, Department of Food and Rural Affairs, London, available at: www.gov.uk/government/statistics/digest-ofwaste-and-resource-statistics-2015-edition

Ding, D., Cooper, R.A., Pasquina, P.F. and Fici-Pasquina, L. (2011), "Sensor technology for smart homes", Maturitas, Vol. 69 No. 2, pp. 131-136

Dittmann, L. (2006), "Der angemessene Grad an Visibilita " $t$ in Logistik-Netzwerken - Auswirkungen von RFID”, Research Report, University of St Gallen, St Gallen.

Dube, L. and Pare, G. (2003), "Rigor in information systems positivist case research: current practices, trends, and recommendations", MIS Quarterly, Vol. 27 No. 4, pp. 597-636.

Dubois, A. and Araujo, L. (2007), "Case research in purchasing and supply management: Opportunities and challenges", fournal of Purchasing and Supply Management, Vol. 13 No. 3, pp. 170-181. doi: 10.1016/j.pursup. 2007.09.002.

Dubois, A. and Gadde, L.E. (2002), "Systematic combining: an abductive approach to case research", fournal of Business Research, Vol. 55 No. 7, pp. 553-560.

Dutton, W.H. (2014), "Putting things to work: social and policy challenges for the Internet of things", Info, Vol. 16 No. 3, pp. 1-21.

Edvardsson, B., Kleinaltenkamp, M., Tronvoll, B., McHugh, P. and Windahl, C. (2014), "Institutional logics matter when coordinating resource integration", Marketing Theory, Vol. 14 No. 3, pp. 291-309.

Eisenhardt, K.M. and Martin, J.A. (2000), "Dynamic capabilities: what are they?", Strategic Management fournal, Vol. 21 Nos 10/11, p. 1105.

El Korchi, A. and Millet, D. (2014), "Conditions of Emergence of OEM's reverse supply chains", fournal of Remanufacturing, Vol. 4 No. 3, pp. 1-17.

Ellinger, A., Shin, H., Northington, W.M., Adams, F.G., Hofman, D. and O'Marah, K. (2012), "The influence of supply chain management competency on customer satisfaction and shareholder value", Supply Chain
Management: An International fournal, Vol. 17 No. 3, pp. 249-262.

Esperon-Migueza, M., Johnb, P. and Jennionsa, I.K. (2013), "A review of integrated vehicle health management tools for legacy platforms: challenges and opportunities", Progress in Aerospace Sciences, Vol. 56, pp. 19-34.

Fawcett, S.E., Magnan, G.M. and McCarter, M.W. (2008), "Benefits, barriers, and bridges to effective supply chain management", Supply Chain Management: An International fournal, Vol. 13 No. 1, pp. 35-48.

Fisher, M.L. (1997), "What is the right supply chain for your product?", Harvard Business Review, Vol. 75 No. 2, pp. 83-93.

Fleischmann, M., Krikke, H.R., Dekker, R. and Flapper, S.D.P.(2000), "A characterisation of logistics networks for product recovery”, Omega, Vol. 28 No. 6, pp. 653-666.

Francis, V. (2008), "Supply chain visibility: lost in translation?", Supply Chain Management: An International fournal, Vol. 13 No. 3, pp. 180-118.

Fuente, M.V., Ros, L. and Cardo's, M. (2008), "Integrating forward and reverse supply chains: application to a metal-mechanic company", International fournal of Production Economics, Vol. 111 No. 2, pp. 782-792.

Gavirneni, S., Kapuscinski, R. and Tayur, S. (1999), "Value of information in capacitated supply chains", Management Science, Vol. 45 No. 1, pp. 16-24.

Ghiassi, M. and Spera, C. (2003), "Defining the internet-based supply chain system for mass customized markets", Computers E Industrial Engineering, Vol. 45 No. 1, pp. 17-41.

Goh, M., De Souza, R., Zhang, A.N., Wei He and Tan, P.S. (2009), "Supply chain visibility - a decision making perspective", IEEE Conference on Industrial Electronics and Applications, IEEE, pp. 2546-2551.

Govindan, K. and Popiuc, M.N. (2014), "Reverse supply chain coordination by revenue sharing contract: a case for the personal computers industry", European fournal of Operational Research, Vol. 233 No. 2, pp. 326-336.

Gubbi, J., Buyya, R., Marusic, S. and Palaniswami, M. (2013), "Internet of Things (IoT): a vision, architectural elements, and future directions", Future Generation Computer Systems, Vol. 29 No. 7, pp. 1645-1660. doi: http:// dx.doi.org/10.1016/j.future.2013.01.010

Guide, J.V.R., Jayaraman, V., Srivastrava, R. and Benton, W.C. (2000), "Supply chain management of recoverable manufacturing systems", Interfaces, Vol. 30 No. 3, pp. 124-142.

Guide, V.D.R., Jr. and Van Wassenhove,L.N. (2002), "The reverse supply chain", Harvard Business Review, Vol. 80 No. 2, pp. 25-26.

Gummesson, E. and Mele, C. (2010), "Marketing as value co-creation through network interaction and resource integration", Fournal of Business Market Management, Vol. 4 No. 4, pp. 181-198.

Gustin, C.M., Daugherty, P.J. and Stank, T.P. (1995), "The effects of information availability on logistics integration", Fournal of Business Logistics, Vol. 16 No. 1, pp. 1-21.

Halldórsson, Á. and Svanberg, M. (2013), "Energy resources: trajectories for supply chain management", Supply Chain 
Management: An International fournal, Vol. 18 No. 1, pp. 66-73.

Holmström, J., Brax, S. and Ala-Risku, T. (2010), "Comparing provider-customer constellations of visibility-based service", Fournal of Service Management, Vol. 21 No. 5, pp. 675-692.

Jagtap, S. and Johnson, A. (2011), "In-service information required by engineering designers", Research in Engineering Design, Vol. 22 No. 4, pp. 207-221.

Johnston, R. (1989), "The customer as employee", International fournal of Operations \& Production Management, Vol. 9 No. 5, pp. 15-23.

Johnstone, S., Dainty, A. and Wilkinson, A. (2009) "Integrating products and services through life: an aerospace experience", International fournal of Operations $\mathcal{E}$ Production Management, Vol. 29 No. 5, pp. 520-538.

Kaipia, R. and Hartiala, H. (2006), "Information-sharing in supply chains: five proposals on how to proceed", The International fournal of Logistics Management, Vol. 17 No. 3, pp. 377-393.

Kiely, D.A. (1998), "Synchronizing supply chain operations with consumer demand using customer data", fournal of Business Forecasting Methods E Systems, Vol. 17 No. 4, pp. 3-9.

Klein, H.K. and Myers, M.D. (1999), "A set of principles for conducting and evaluating interpretive field studies in information systems", MIS Quarterly, Vol. 23 No. 1, pp. 67-93. doi: 10.2307/249410.

Klueber, R. and O'Keefe, R.M. (2013), "Defining and assessing requisite supply chain visibility in regulated industries", fournal of Enterprise Information Management, Vol. 26 No. 3, pp. 295-315.

Kocabasoglu, C., Prahinski, C. and Klassen, R.D. (2007), "Linking forward and reverse supply chain investments:the role of business uncertainty", fournal of Operations Management, Vol. 25 No. 6, pp. 1141-1160.

Kulp, S.C. (2002), "The effect of information precision and information reliability on manufacturer-retailer relationships", The Accounting Review, Vol. 77 No. 3, pp. 653-677.

Kusiak, A. (2002), "Integrated product and process design: a modularity perspective", Fournal of Engineering Design, Vol. 13 No. 3, pp. 223-231. doi: 10.1080/ 09544820110108926.

Lamming, R. (1996), "Squaring lean supply with supply chain management", International fournal of Operations $\mathcal{E}$ Production Management, Vol. 16 No. 2, pp. 183-196.

Lamming, R.C., Caldwell, N.D., Harrison, D.A. and Phillips, W. (2001), "Transparency in supply relationships: concept and practice", Fournal of Supply Chain Management, Vol. 37 No. 4, pp. 4-10.

Lee, H.L. (2000), "Creating value through supply chain integration", Supply Chain Management Review, Vol. 4 No. 4, pp. 30-36.

Lee, H.L., So, K.C. and Tang, C.S. (2000), "The value of information sharing in a two-level supply chain", Management Science, Vol. 46 No. 5, pp. 626-643.

Lee, H.L. and Whang, S. (2000), "Information sharing in a supply chain", International Fournal of Manufacturing Technology and Management, Vol. 1 No. 1, p. 79.
Loomba, A.P.S. and Nakashima, K. (2012), "Enahancing value in reverse supply chains by sorting before product recovery", Production Planning and Control, Vol. 23 Nos 2/3, pp. 205-215.

Luger, E. and Speed, S. (2014), "Seeing behind closed doors. In The co-productions of data-based living (1): mediated life: technologies, affect, routine", RGS-IBG Annual International Conference, 26-29 August, Royal Geographical Society (with IBG), London.

McCrea, B. (2005), "EMS completes the visibility picture", Logistics Management, Vol. 44 No. 6, pp. 57-61.

Majeed, B.A. and Brown, S.J. (2006), "Developing a well-being monitoring system - modeling and data analysis techniques", Applied Soft Computing, Vol. 6, pp. 384-393.

Matsko, M.J. (2005), "Method and apparatus for storing retail performance metrics", US Patent number US 6929177 B2.

Maull, M., Geraldi, J. and Johnston, R. (2012), "Service supply chain: a customer perspective", fournal of Supply Chain Management, Vol. 48 No. 4, pp. 72-86.

McFarlane, D. and Sheffi, Y. (2003), "The impact of automatic identification on supply chain operations", International Fournal of Logistics Management, Vol. 14 No. 1, pp. 1-17.

McNaught, K.R. and Zagorecki, A.T. (2011), "Modelling techniques to support the adoption of predictive maintenance", in Ng, I., Parry, G., Wilde, P., McFarlane, D. and Tasker, P. (Eds), Complex Engineering Service Systems: Concepts and Research, Chapter 15, Springer, London, pp. 277-296.

Mills, J., Parry, G. and Purchase, V. (2011), "Understanding the clients aspirations and fears", in Ng, I., Parry, G., Wilde, P., McFarlane, D. and Tasker, P. (Eds), Complex Engineering Service Systems: Concepts and Research, Springer, London, pp. 87-103.

Miorandi, D., Sicari, S., Pellegrini, D.F. and Chlamtac, I. (2012), "Internet of things: vision, applications and research challenges", Ad Hoc Networks, Vol. 10 No. 7, pp. 1497-1516.

Moeller, S. (2008), "Customer integration - a key to an implementation perspective of service provision", fournal of Service Research, Vol. 11 No. 2, pp. 197-210. doi: 10.1177/ 1094670508324677.

Mohr, J. and Sohi, R.S. (1995), "Communication flows in distribution channels: impact on assessments of communication quality and satisfaction", Fournal of Retailing, Vol. 71 No. 4, pp. 393-416.

Mohr, J. and Spekman, R. (1994), "Characteristics of partnership success - partnership attributes, communication behavior, and conflict resolution techniques", Strategic Management fournal, Vol. 15 No. 2, pp. 135-152.

Monekosso, D.M. and Remagnino, P. (2013), "Data reconciliation in a smart home sensor network", Expert Systems with Applications, Vol. 40 No. 8, pp. 3248-3255.

Mulligan, C. (2014), ICT and The Future of Utilities, Networked Society Lab, Ericsson, available at: www. ericsson.com/res/docs/2014/ict-and-the-future-of-utilities. pdf 
Ng, I.C.L. (2014), Creating New Markets in the Digital Economy: Value \& Worth, Cambridge University Press, Cambridge, MA.

Nikander, P., Rao, V.K., Liuha, P. and Tenhunen, H. (2013), "ELL-i: An inexpensive platform for fixed things", Scalable Computing: Practice and Experience, Vol. 14 No. 3.

Nissenbaum, H. (2004), "Privacy as contextual integrity", Washington Law Review, Vol. 79 No. 1, pp. 119-157.

Nissenbaum, H. (2011), "A contextual approach to privacy online", Daedalus, Vol. 140 No. 4, pp. 32-48.

NIST (1993), Integration Definition for Function Modeling (IDEF0), National Institute of Standards and Technology, Draft Federal Information Processing Standards Publication, NIST, Gaithersburg, MD, available at: www. idef.com/pdf/idef0.pdf, p. 183.

O'Cass, A. and Ngo, L.V. (2011), "Examining the firm's value creation process: a managerial perspective of the firm's value offering strategy and performance", British Fournal of Management, Vol. 22 No. 4, pp. 646-671.

Oliver, H. (2015), "The automagic box of beauty: a prototypical smart device as use case example for user-centered decision support via the hub-of-all-things", SENSORNETS 2015, Angers, Franc, 11-13 February. doi: $10.5220 / 0005330000910096$.

ONS - Office of National Statistics (2013), Family Spending, 2013 ed., ONS, London, available at: www.ons.gov.uk/ons/ rel/family-spending/family-spending/2013-edition/index. html

PACE (2007), "Z-Wave: the other wireless standard", Process \& Control Engineering (PACE), Vol. 60 No. 3, p. 27.

Pang, Z., Chen, Q., Han, W. and Zheng, L. (2015), "Value-centric design of the internet-of-things solution for food supply chain: value creation, sensor portfolio and information fusion", Information Systems Frontiers, Vol. 17 No. 2, pp. 289-319.

Payne, A.F., Storbacka, K. and Frow, P. (2008), "Managing the co-creation of value", fournal of the Academy of Marketing Science, Vol. 36 No. 1, pp. 83-96.

Penrose, E. (1959), The Theory of the Growth of the Firm, Blackwell, Oxford.

Perera, T. and Liyanage, K. (2001), "IDEF based methodology for rapid data collection", Integrated Manufacturing Systems, Vol. 12 No. 3, pp. 187-194.

Ravald, A. and Grönroos, C. (1996), "The value concept and relationship marketing", European fournal of Marketing, Vol. 30 No. 2, pp. 19-30.

Sampson, S.E. (2012), "Visualizing service operations", Fournal of Service Research, Vol. 15 No. 2, pp. 182-198.

Santibanez-Gonzalez, E.D.R. and Diabat, A. (2013), "Solving a reverse supply chain design problem by improved Benders decomposition schemes", Computers $\mathcal{E}$ Industrial Engineering, Vol. 66 No. 4, pp. 889-898.

Santucci, G. (2011), "The Internet of things: the way ahead", in Vermesan, O. and Friess, P. (Eds), Internet of Things-Global Technological and Societal Trends From Smart Environments and Spaces to Green ICT, Chapter 3, River Publishers, Aalborg, p. 53.

Sarkis, J. (2012), "A boundaries and flows perspective of green supply chain management", Supply Chain
Management: An International fournal, Vol. 17 No. 2, pp. 202-216.

Schoenthaler, R. (2003), "Creating real-time supply chain visibility", International fournal of Electronic Business, Vol. 29 No. 9, p. 12.

Siegel, D., Ly, C. and Lee, J. (2012), "Methodology and framework for predicting helicopter rolling element bearing failure", IEEE Transactions on Reliability, Vol. 61 No. 4, pp. 846-857.

Simatupang, T.M. and Sridharan, R. (2005), "The collaboration index: a measure for supply chain collaboration", International fournal of Physical Distribution E Logistics Management, Vol. 35 No. 1, pp. 44-62.

Simatupang, T., Wright, A.C. and Sridharan, R. (2002), "The knowledge of coordination for supply chain integration", Business Process Management Fournal, Vol. 8 No. 3, pp. 289-308.

Smart, A. (2005), "Exploring supply chain opportunities in the UK utilities sector and the supporting role of eMarketplaces", Supply Chain Management: An International fournal, Vol. 10 No. 4, pp. 264-271.

Soh, C., Chua, C.E.H. and Singh, H. (2011), "Managing diverse stakeholders in enterprise systems projects: a control portfolio approach", Fournal of Information Technology, Vol. 26 No. 1, pp. 16-31.

Speed, C. and Barker, C. (2014), "New domestic locations: reconfiguring the home through the Internet of things", 20th International Symposium on Electronic Art, Dubai, 3-6 November.

Speed, C. and Luger, E. (2015), "The Challenge of sensing data in the home: inferring domestic practice", Association of American Geographers (AAG) Annual Meeting, Chicago, IL, 21-25 April.

Srivastava, S.K. (2008), "Network design for reverse logistics",Omega, Vol. 36 No. 4, pp. 535-548.

Swaminathan, J.M. and Tayur, S.R. (2003), "Models for supply chains in e-business", Management Science, Vol. 49 No. 10, pp. 1387-1406. doi: 10.2307/4134012

Thierry, M., Salomon, M., van Nunen, J. and Van Wassenhove, L. (1995), "Strategic issues in product recovery management", California Management Review, Vol. 37 No. 2, pp. 114-134.

Tibben-Lembke, R.S. and Rogers, D.S. (2002), "Differences between forward and reverse logistics in a retail environment", Supply Chain Management: An International fournal, Vol. 7 No. 5, pp. 271-282.

Tolmie, P., Crabtree, A., Rodden, T., Luger, E. and Colley, J (2016), "This has to be the cats", Personal Data Legibility in Networked Sensing Systems, to appear in Proceedings of Computer-Supported Cooperative Work and Social Computing [CSCW] 2016, San Francisco, CA, 27 February-2 March.

Umar, A. (2005), "IT infrastructure to enable next generation enterprises", Information Systems Frontiers, Vol. 7 No. 3, pp. 217-256.

Vandermerwe, S. and Rada, J. (1988), "Servitization of business: adding value by adding services", European Management Fournal, Vol. 6 No. 4, pp. 314-324.

Vargo, S.L. and Lusch, R.F. (2004), "Evolving to a new dominant logic for marketing", fournal of Marketing, Vol. 68 No. 1, pp. 1-17. 
Vargo, S.L. and Lusch, R.F. (2008), "Service-dominant logic: continuing the evolution", Fournal of the Academy of Marketing Science, Vol. 36 No. 1, pp. 1-10.

Vargo, S.L., Maglio, P.P. and Akaka, M.A. (2008), “On value and value co-creation: a service systems and service logic perspective", European Management fournal, Vol. 26 No. 3, pp. 145-152.

Vermesan, O., Friess, P., Guillemin, P., Gusmeroli, S., Sundmaeker, H., Bassi, A., Jubert, I.S., Mazura, M., Harrison, M. and Eisenhauer, M. (2011), Cluster SRA 2011, "Chapter internet of things strategic research roadmap", European Research Cluster on the Internet of Things, pp. 9-52.

Vitasak, K. (2013), Supply Chain Management Terms and Glossary, Council for Supply Chain Management Professionals, available at: http://cscmp.org/sites/default/ files/user_uploads/resources/downloads/glossary-2013.pdf

Waterwise (2012), Waterwise Fact Sheet, Waterwise, London, available at: www.waterwise.org.uk/data/resources/25/ Water_factsheet_2012.pdf

Weber, M.M. and Kantamneni, S.P. (2002), "POS and EDI in retailing: an examination of underlying benefits and barriers", Supply Chain Management: An International Fournal, Vol. 7 No. 5, pp. 311-331.

Wei, H.L and Wang, E.T.G. (2010), "Visibility IT and strategy", European Fournal of Information Systems, Vol. 19 No. 2, pp. 238-249.

Wells, P. and Seitz, M. (2005), "Business models and closed-loop supply chains: a typology", Supply Chain Management: An International fournal, Vol. 10 No. 4, pp. 249-251.

Whipple, J.M., Frankel, R. and Daugherty, P.J. (2002), "Information support for alliances: performance implications", fournal of Business Logistics, Vol. 23 No. 2, pp. 67-82.

Williams, B.D. and Waller, M.A. (2011), "Top-down vs bottom-up demand forecasts: the value of shared point-of-sale data in the retail supply chain", Fournal of Business Logistics, Vol. 32 No. 1, pp. 17-26.

Wilson, D.H., Long, A.C. and Atkeson (2005), "A context-aware recognition survey for data collection using ubiquitous sensors in the home", CHI '05 Extended Abstracts on Human Factors in Computing Systems, Portland, OR, 2-7 April 2005. doi: 10 1145/1056808.1057042.

WRAP (2014), Switched on to Value, Wrap, Oxon, available at: www.wrap.org.uk (accessed 11 September 2014).

Yin, R.K. (1994), Case Study Research, Design and Methods, 2nd ed., Sage, Thousand Oaks, CA.

Yu, Z., Yan, H. and Cheng, T.C.E. (2001), "Benefits of information sharing with supply chain partners", Industrial Management \& Systems, Vol. 101 No. 3, pp. 114-119.

Zhang, A.N., Goh, M., de Souza, R. and Meng, F. (2011), "Conceptual modelling for supply chain inventory visibility", International fournal of Production Economics, Vol. 133 No. 2, pp. 578-585.

Zhou, L., Chong, A.Y.L. and Ngai, E.W.T. (2015), "Special issue supply chain management in the era of the internet of things", International fournal of Production Economics, Vol. 159, pp. 1-3.

\section{Further reading}

Adenso-Diaz, B., Moreno, P., Gutierrez, E. and Lozano, S. (2012), "An analysis of the main factors affecting bullwhip in reverse supply chains", International fournal of Production Economics, Vol. 135 No. 2, pp. 917-928.

Baines, T. and Lightfoot, H.W. (2014), "Servitization of the manufacturing firm: Exploring the operations practices and technologies that deliver advanced services", International Fournal of Operations \& Production Management, Vol. 34, No. 1, pp. 2-35.

Brax, S. and Jonsson, K. (2009), "Developing integrated solution offerings for remote diagnostics: a comparative case study of two manufacturers", International fournal of Operations \& Production Management, Vol. 29 No. 5, pp. 539-560.

Chen, F. (1998), "Echelon reorder points, installation reorder points, and the value of centralized information", Management Science, Vol. 44 No. 2, pp. 221-234.

Chen, F., Drezner, Z., Ryan, J.K. and Simchi-Levi, D. (2000), "Quantifying the bullwhip effect in a simple supply chain: the impact of forecasting, lead times and information", Management Science, Vol. 46 No. 3, pp. 436-443.

Disney, S.M. and Towill, D.R. (2003), "Vendor-managed inventory and bullwhip reduction in a two-level supply chain", International Fournal of Operations \& Production Management, Vol. 23 No. 6, pp. 625-650.

IDEF0 (1993), Integration Definition for Function Modelling, Draft Federal Information Processing Standards Publications (FIPS PUBS) 183.

Jayaraman, V., Ross, A.D. and Agarwal, A. (2008), "Role of information technology and collaboration in reverse logistics supply chains", International foumal of Logistics: Research and Applications, Vol. 11 No. 6, pp. 409-425.

Lee, H.L., Padmanabhan, V. and Whang, S. (1997), "Information distortion in a supply chain, the bullwhip effect", Management Science, Vol. 43 No. 4, pp. 546-558.

$\mathrm{Ng}$, I.C.L. and Smith, L.A. (2012), "An integrative framework of value", in Vargo, S.L. and Lusch, R.F. (Eds), Special Issue - Toward a Better Understanding of the Role of Value in Markets and Marketing (Review of Marketing Research, Vol. 9, pp. 207-243.

Ng, I.C.L., Parry, G., Wilde, P., McFarlane, D. and Tasker, P. (2011), Complex Engineering Service Systems: Concepts and Research, Springer, London. ISBN9780857291882.

ONS - Office of National Statistics (2015), Retail Sales, September 2015, ONS, London, available at: www.ons.gov. uk/ons/rel/rsi/retail-sales/september-2015/index.html

\section{About the authors}

Glenn C. Parry, PhD (Cantab) is an Associate Professor of Strategy and Operations Management at the University of the West of England, UK. His work aims to capture leading practice, moving companies forward through transformations based on data-driven analysis. He has published in a number of international journals and has published the books, "Build to Order: The Road to the 5-day Car", "Complex Engineering Service Systems" and "Service Design and Delivery". His interests include value, power, business models, visibility and 
servitisation. Glenn C. Parry is the corresponding author and can be contacted at: glenn.parry@uwe.ac.uk

Dr Saara A. Brax is an Academy Postdoctoral Researcher at Aalto University, School of Science. She has published pioneering work in the area of servitisation of manufacturing companies. Her research interests are in the areas of service management and operations in business-to-business and industrial contexts, including service design, servitisation of manufacturing companies, service processes, service concepts, service systems, service modularity and architecture and service offering development.

Roger S. Maull is a Professor of Management Systems in the University of Surrey Business School and a founder member, with Prof Alan Brown, of Surrey's Centre for the Digital Economy (CoDE). His current research is informed by two major RCUK research grants, NEMODE and the HAT.
Together, they have taken his research into a new phase: considering the implications of the Digital Revolution for businesses and society. He contends that we are in the throes of a massive change driven by technologies, such as the Internet of Things, and the advent of personal data.

Irene C.L. Ng is a Professor of Marketing and Service Systems and the Director of the International Institute for Product and Service Innovation at WMG, University of Warwick. Her research lies in the transdisciplinary understanding of value, creating, designing, pricing, contracting and innovating based on value, embedded within new economic and business models of complex service systems. She is the Principal Investigator of the HAT project and has published numerous articles and is the author of the highly acclaimed "Creating New Markets in the Digital Economy" published by Cambridge University Press.

For instructions on how to order reprints of this article, please visit our website: www.emeraldgrouppublishing.com/licensing/reprints.htm

Or contact us for further details: permissions@emeraldinsight.com 